Tourism 2020, 30/1

\author{
Krzysztof Cieślikowski \\ https://orcid.org/0000-0002-9249-6335 \\ Jerzy Kukuczka University of Physical Education in Katowice \\ Department of Sport and Tourism Management \\ k.cieslikowski@awf.katowice.pl \\ Andrius Brusokas \\ https://orcid.org/0000-0001-8913-1274 \\ Kaunas College / University of Applied Sciences \\ Faculty of Business \\ Tourism and Leisure Management Department \\ andrius.brusokas@go.kauko.lt
}

\title{
SELECTED ATTRACTIVENESS FACTORS OF ACADEMIC CONFERENCES AS A PRODUCT ON THE INTERNATIONAL TOURISM MARKET
}

\begin{abstract}
The paper identifies selected determinants of attractiveness of international academic conferences as products on the contemporary international tourism market, especially on the business tourism market. To achieve this aim, methods of analysing the literature, reports, synthesis, along with passive and active observation were used. In addition, a direct survey using a research questionnaire via a website and addressed to participants on an Erasmus International Week in Kaunas was made. Some of the most important conditions of the attractiveness of the conference for participants, including transport and information accessibility as well as to the originality of the destination and the leisure program for participants, were indicated. Contemporary international academic conferences lasting a few days epitomize multiple products on tourism market. The article is empirical, but it also presents ideas for the development of conferences as attractive products in the contemporary economy of the European Union.
\end{abstract}

Keywords: tourism product, system product, meetings industry, international conference.

\section{INTRODUCTION}

The global tourism market is still developing (WTTC, 2018). Business tourism is developing as a very important part of tourism (related to travel to meetings organised outside the place of permanent residence of participants). It is driven by the needs of organizers and the professional activity of the visitors. The development of products offered on the business tourism market should be the result of a recognition of the needs of their participants (Malekmohammadi, Mohamed, Ekiz, 2011; Breiter, Milman, 2006). This may contribute to their better management, the greater satisfaction of the visitors and to higher delegate expenditure at the destination.

The aim is to identify the determinants of the attractiveness of international conferences as products on the tourism market through the example of an Erasmus+ International Week (EIW) conference. To achieve this, methods of analysing the literature, reports, passive and active observations were used. The authors prepared some questions located on the survio.com website and addressed to the participants of the conference. The main criteria used for the selection of a conference by participants were chosen after reviewing the literature on the subject. The most important determinants are different kinds of transport and current information, as well as to the originality of the destination and leisure program.

Contemporary international conferences, especially those which are academic, are multiple system products on the tourism market (Niemczyk, 2014; Żabiński, 2012). There are certain determinants for tourism attractiveness that have been identified and recognised as success factors for such products as a result of the author's own research. An EIW conference in Kaunas, Lithuania in 2018 was chosen and a direct survey of the participants was conducted. The authors are 
aware of the limitations of this research. Organizers and managers of business tourism in destinations (both companies and the local administration) can use the conference success factors described here to improve the results of such professional events.

\section{INTERNATIONAL CONFERENCES AS PRODUCTS ON THE TOURISM MARKET}

Tourism is a social, cultural and economic phenomenon that entails the movement of people to countries or places outside their usual environment for personal or business/professional purposes comprising the activities carried out there (UN WTO, 2010). There are various forms of tourism separated according to different criteria. If the main purpose (reason) of the trip, and the methods of financing and professional activity are taken into account, it can be divided into leisure tourism and business tourism.

Business tourism is related to those travelling for business purposes and is described by the acronym MICE: meetings, incentives, conventions, exhibitions (Dwyer, Forsyth, 1997) or the term 'meeting industry' is used as a synonym (UN WTO, 2010). At the same time, the term business trip may refer to a 'face to face' meeting as well as various forms of group meetings. The term business tourism preferably refers to travel for group meetings (Davidson, Cope, 2003). The UN WTO (2014), for statistical purposes, specifies that group meetings counted as business tourism are those with a minimum of 10 participants, lasting four hours or more, in a rented room. Entities engaged in the planning and implementation of such a meeting are on the supply side of the business tourism market, while institutional 'purchasers' and participants, are on the demand side (Cieślikowski, 2014).

The business tourism market can be separated from the general term due to the object of the transaction, which is a business meeting (business event) on the market. Planning and implementation require the cooperation of many different entities providing strictly tourist-oriented services as well as those operating on markets other than tourism, and the local government of the conference destination (Berbeka, Borodako, Niemczyk, Seweryn, 2014; Borodako, Berbeka, Rudnicki, 2014).

The term 'conference' refers to many types which differ in their number of participants, frequency of implementation, location, financing methods, type of organizer, time of implementation, topics, etc (Cieślikowski, 2014; Sidorkiewicz, 2014; Swarbrooke, Horner 2011; Weber, Chon, 2009).

Adding the word 'international' to the name of the conference suggests a larger scale, significance, use of several languages, as well as participants from other countries (Numella, 2017). International conferences usually last several days, and some of the participants come from abroad (ICCA, 2007; UIA, 2018). Many studies and reports show that foreign participants at such meetings generate higher expenditure in the destination than domestic visitors (Berbeka, Borodako, Niemczyk, Seweryn, 2014; Nummela, 2017). Due to the importance of international conferences, the participants are usually opinion leaders in their professional environment, attaching great importance to their own development as well as that of the organization that has delegated them. Some authors emphasise that the participants of conferences use basic tourist services, and in their leisure time outside the conference program, satisfy the same needs as those of other. This similarity applies to the use of the general infrastructure of the city, cultural facilities and other tourist attractions (Swarbrooke, Horner, 2011).

Analysing contemporary international conferences, treated as products of enterprises and destinations, it can be noted that they have many attributes of system products. According to Żabiński (2012), such products (including complex services, as well as organization and conference services) are:

- ready to satisfy a specific complex of needs and expectations of buyers and solve several of their problems at the same time,

- ready to meet needs assigned to more than one level,

- usually characterised by a high technological level,

- generally innovative products from a market/ consumer perspective,

- capable of improvement in their use or further development,

- branded products (by definition, new product categories),

- characterised by network connections (they are often created when a producer/ manufacturer/ service provider interacts with networks of component suppliers or commercial agents).

The products meet the needs of visitors from abroad, too who are interested in various services (local travel, accommodation, restaurants, free time services, guide services, etc.). They expect all needs to be met by the organisers (according to Maslow's hierarchy of needs) during the conference. The participants usually spend more money in the destination than leisure tourists (EIC, 2018), but also expect a high level of services supported by the latest technology (Dwyer, Forsyth, Spurr, 2004). But for organizers and destinations it is very important to understand that conferences can be a branded product (Ayaz, Samata, 2017; Cieślikowski, 2015; Malava, Bénaroya, Digout, Szapiro, 2013; Rogers, Davidson, 2016) and their process of planning and organising requires the cooperation of many entities (Borodako, Kožić, 2016; Crouch, Louviere, 2004). The identification and measurement of participant 
motivations (official and unofficial) are very important for the attractiveness of a conference as a product on the tourism market.

\section{SELECTED SUCCESS FACTORS OF CONFERENCES AS EXEMPLIFIED BY EIW IN KAUNAS}

\subsection{RESEARCH METHODOLOGY}

The success of a tourism product can be considered from the point of view of satisfying the needs of visitors (Lemanowicz, Puciata, 2010) and other entities involved in its planning, its organisation and its offer (Żemła, 2010). There are many studies identifying criteria for choosing venues and destinations in the literature (Cieślikowski, 2014; Crouch, Ritchie, 1997; Fenich, 2001; Gugg, Hank-Haase, 1995; Oppermann, 1996). However, international conferences are very diverse products and meet of the needs of many different groups of participants (both visitors and residents). There are several criteria differentiating these: duration, place, type of participant, motive for participation, etc.

The success of such a tourism product can be understood as the greatest satisfaction of the most important individual needs. It seems very important to identify the tools and forms of communication preferred by participants when they are expecting and looking for information, the means of transport used to arrive there and to satisfy a range of other needs met in the destination itself (accommodation, security, sightseeing etc.).

Taking into consideration the main goals of participants, the sources of financing and the type of insti tutions delegating, it is possible to distinguish 'international conferences' - academic and cultural meetings in which most of the guests came from abroad - from the general group.

An example of such a conference is an 'EIW' type conference. EIWs are multifarious conferences (including several smaller events) that usually consist of academic conferences, workshops and other events and trips with interesting leisure programs (sightseeing, learning about the history of the city, country, cultural performances, etc.). Research centres, universities and schools in EU countries and beyond implement them (Smith, 2018).

The main purposes of participants at the conferences are broadening knowledge, exchanging academic findings, establishing new professional relations, etc. It should be noted that participants will represent different academic centres.

Erasmus+ is an EU administration program for the education, training and development of sport in Europe which will last until 2020. The program is addressed to both individuals and institutions who qualify can take part in EIW conferences or organize their own (ECEC, 2014; European Commission, 2018).

The object of the authors' research was to identify the determinants of the attractiveness of such conferences. Forms of communication, the means of transport used by participants, the main criteria for the selection of an international conference, as well as the motivations of both official and unofficial participants were identified.

Indirect research (desk research) and direct (questionnaire) surveys were carried out. EIW conferences from 2014 to 2018, concentrating on 2017, were subjected to statistical analysis. A direct survey (using questionnaires) concerned participants of the EIW conference in Kaunas (Lithuania) from 19 to 23 March 2018. To create a questionnaire, the authors used elements of the 'servqual' methodology (Zeithaml, Parasuraman, Berry, 1990), as well as selecting the evaluation criteria (features) of conference services from existing studies regarding the conference market (Oppermann, 1995; Oppermann, 1996). To measure the quality of services offered to the participants and to identify the success factors of an international conference a questionnaire was used too.

As a result of a review of the literature and reports on business tourism (NBTC, 2015; Zhang, Leung, Qu, 2007) and other events, including cultural (Ayaz, Samata, 2017) and sporting events (Agha, 2011; Cieślikowski, Brusokas, 2017), a list of 17 factors which, according to the authors, have a significant impact on the choice of location and the evaluation of a conference (service features) was prepared.

The five-degree Likert scale (from 1 to 5 ) was used to assess the validity and fulfilment of individual factors (Pal, Joshi, Kale, Chandel, 2015). In the case of validity: 1 - meant 'not important for participants' and 5 - 'very important'; while in the case of fulfilment: 1 - 'not fulfilled' in the opinion of participants, and 5 - 'very well fulfilled'. A questionnaire was created and opened on the survio.com website.

The 57 foreign participants of EIW - the conference organized by Kauno Kolegija in Kaunas, from 19 to 23 March 2018 - were the research sample. The questionnaire was prepared only for guests from abroad. The total number of participants in this conference was 90, and the 57 foreigners were from 18 different countries and from 29 research centres. From May 1-10, 2018, the participants were sent via e-mail an online questionnaire and a request to respond; 56 answered and the results were subjected to a statistical analysis and interpretation. The authors are aware of the small size of the research sample, however these studies may still be helpful, especially in the selection of key elements of the evaluation of an international academic conference and the research methodology. However, the methodology and results can be used to improve 
and develop the product and can help to achieve market success by companies involved in the process of preparation and implementation.

\subsection{FINDINGS}

The total number of EIW conferences that were registered on the staffmobility.eu database (Staff weeks search, 2018), on August 30, 2018 was 728. The analysis of information contained on the websites of their organizers makes it possible to see that they are academic conferences, with many workshops and cultural events in free time. 30 to 90 people usually attend them, mainly from other countries. Participation in most is free, and the costs of travelling to the conference and staying in destination accommodation are covered in whole or in part by Erasmus+ program funds.

Respondents to the survey (participants at the EIW conference in Kaunas, Lithuania) came from 29 research centres and from 18 different countries. $26 \%$ came from neighbouring countries, with the remaining from countries elsewhere in Europe (58\%), and outside $(16 \%)$. The participants from Lithuania were excluded from the study (the organizer of the event).

In the questionnaire, the participants were asked how they had first obtained information about the event. Most pointed to their supervisor/boss at their work (43\% of responses), while $29 \%$ indicated e-mail and friends (Figure 1). It ought to be noted that participants could indicate more than one answer.

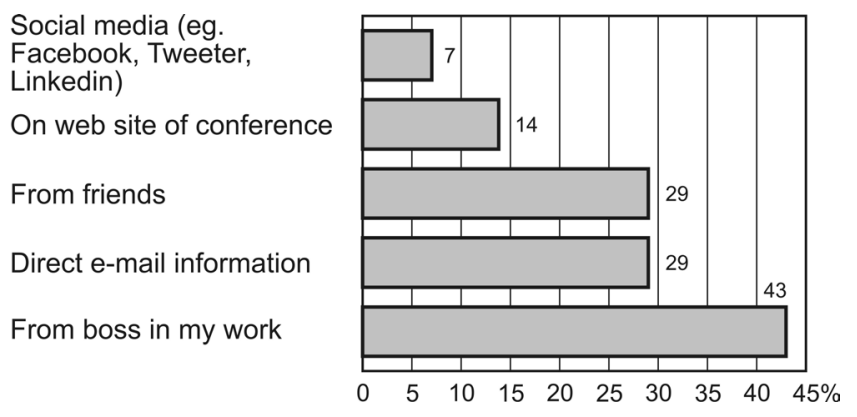

Figure 1. Ways of searching for information by EIW participants in Kaunas

Source: based on research (Cieślikowski, Brusokas, 2019)

These indications show the strong business relationship of EIW. Therefore, communication, promotion and information should be directed at decision-makers in a given organisation or directly to interested parties using direct marketing and personal meetings.

The respondents were asked about their main motivations. They determined 11 likely motivations, on a scale of 1 to 5 (1- not important, to 5 - very important). The obtained results (Table 1 ) indicate that the most important motivations are knowledge acquisition (4.29), new
Table 1. The key motivations for EIW participants

\begin{tabular}{|c|l|c|}
\hline No. & \multicolumn{1}{|c|}{ Motivators } & $\begin{array}{c}\text { Average } \\
\text { rate }\end{array}$ \\
\hline 1 & Acquire knowledge & 4.29 \\
\hline 2 & New professional contacts & 4.21 \\
\hline 3 & Promotion of their own organization & 4.00 \\
\hline 4 & 'Personal relations' & 3.86 \\
\hline 5 & Personal development of qualifications & 3.57 \\
\hline 6 & University's (organizer) popularity & 3.57 \\
\hline 7 & Personalised participation certificate & 3.43 \\
\hline 8 & The possibility of recreation in free time & 3.36 \\
\hline 9 & Low participation costs & 3.14 \\
\hline 10 & $\begin{array}{l}\text { Other attractions, e.g. membership cards, } \\
\text { freebies }\end{array}$ & 2.64 \\
\hline 11 & $\begin{array}{l}\text { A short distance from the university } \\
\text { to the accommodation }\end{array}$ & 2.57 \\
\hline
\end{tabular}

Source: based on research (Cieślikowski, Brusokas, 2019).

professional contacts (4.21) and the promotion of their own organisation (4.00).

Another question was related to the level of fulfilment of these factors by the EIW organized by Kauno Kolegija in 2018 (the same factors were listed: 1 - fulfilment was 'not enough', up to 5 - 'completely'). The difference between the results for individual features/ factors (the difference between expectations and fulfilment) allows an analysis of the attractiveness of the university and the city as perceived by the foreign EIW participants.

The questionnaire responses of EIW participants show that what is important during the selection of a conference are 'novelty of the host university' (4.0) and 'information availability of this EIW' (4.0). On the other hand, the least important were 'accessibility by car' (2.50), 'many shopping centres', 'other business conferences and events at the same time' (these last two features have an average rating of 2.43).

The questionnaire contains two questions related to the 17 different significant features which, according to the authors, influence the success of a well-organized EIW conference. The first is related to how important these features are for the participant when choosing a conference, and the other to what extent these features were met by EIW in Kaunas. On a scale of 1 to 5, the participants had to refer to each feature, 1 - not important to 5 - very important. Next, the participants assessed the fulfilment of these features by the organizers on a scale from 1 to 5, 1 - 'poorly satisfied' to 5 - 'met very well'.

The authors calculated the average for each characteristic, assigned a rating ('rate of importance' in Table 2) and fulfilment ('rate of fulfilment' in Table 2) and compared fulfilment to expectation (the average of rate 
Table 2. Choice factors for a conference and their fulfilment in the opinion of participants of EIW in Kaunas in 2018

\begin{tabular}{|c|c|c|c|c|}
\hline No. & Factors & $\begin{array}{l}\text { The rate of importance } \\
\text { (Expectations) }\end{array}$ & $\begin{array}{l}\text { The rate } \\
\text { of fulfilment }\end{array}$ & Result \\
\hline 1 & Novelty of host university & 4.00 & 4.14 & 0.14 \\
\hline 2 & Information availability of this EIW & 4.00 & 4.14 & 0.14 \\
\hline 3 & Diversified conference program & 3.93 & 3.86 & -0.07 \\
\hline 4 & Opportunity to explore the destination and the surrounding area & 3.93 & 3.71 & -0.21 \\
\hline 5 & Prior contact with this university & 3.79 & 4.50 & 0.71 \\
\hline 6 & Novelty of host country & 3.71 & 4.14 & 0.43 \\
\hline 7 & Novelty of host destination & 3.64 & 4.21 & 0.57 \\
\hline 8 & Faculties at this university are similar to my own & 3.64 & 4.14 & 0.50 \\
\hline 9 & Accessibility by public transportation & 3.64 & 3.86 & 0.21 \\
\hline 10 & Many cultural facilities & 3.64 & 4.00 & 0.36 \\
\hline 11 & Varied gastronomic base & 3.21 & 3.86 & 0.64 \\
\hline 12 & Many green areas & 3.14 & 3.93 & 0.79 \\
\hline 13 & Many cultural and sporting events at the same time & 3.00 & 3.64 & 0.64 \\
\hline 14 & Varied accommodation base & 3.00 & 3.86 & 0.86 \\
\hline 15 & Accessibility by car & 2.50 & 3.00 & 0.50 \\
\hline 16 & Many shopping centres & 2.43 & 3.86 & 1.43 \\
\hline 17 & Other conferences and business events at the same time & 2.43 & 2.86 & 0.43 \\
\hline
\end{tabular}

Source: based on research (Cieślikowski, Brusokas, 2019).

of fulfilment was subtracted from the average rating of expectation). The results expressed the level of success of the organizers in relation to the individual criteria.

Almost all the factors that were evaluated (Table 2) positively show the difference between fulfilment and expectation. Only the 'diversified conference program' $(-0.07)$ and the 'opportunity to explore the destination and the surrounding area' (-0.21) did not meet the expectations of the participants.

What was most important for the participants when selecting the conference were 'novelty of host university' (average rating of 4.0) and 'information availability of this EIW (4.0). The level of fulfilment of these features was greater than expected. The least important were 'many shopping centres', 'other conferences and business events at the same time' (both with an average rating of 2.41). In the case of these two features, the level of fulfilment exceeded expectations and EIW participants were surprised by the shopping centres in the city (expectation exceeded by 1.43).

In the general assessment of the EIW in Kaunas, it should be noted that the participants were very satisfied with 'prior contact with this university' (average fulfilment was 4.5). The following features attracted attention 'novelty of host destination', 'novelty of host country', 'novelty of host university' as well as 'faculties at this university are similar to my own', 'information availability of this EIW' (for all these features the average score was above 4 ).

\section{DISCUSSION}

The results of the research indicate the specificity of international EIW-type conferences and the authors determined the success factors of this product on the modern business tourism market from the point of view of the expectations of the participants.

The specificity of an EIW conference is reflected in their seasonality (most are organised in the spring). For other conferences, research indicated autumn and spring as major periods. In addition, these conferences are open to all those eligible whose criteria are described in the Erasmus+ program rules (European Commission, 2018). The main purpose is related to the professional and academic activity of participants and their institutions (universities). Participants have a lot of freedom to choose a conference, destination and the services they will use (type of transport, accommodation, etc.). Funding is received both from Erasmus+ program funds and from the participants. For an efficient communication process between the organisers and future participants, it is necessary to focus on establishing prior knowledge of key persons in partner universities and transferring information directly to them (e.g. using electronic mail) so that they can recommend a conference and even send an employee. An important factor in the selection of an EIW meeting by participants was an earlier conference at the university. Similar results in terms of preferred methods of communication (focused 
on personal sales, direct marketing and public relations) can be noted in the research carried out on the participants of other conferences (EMS, 2017; Nummela, 2017). This way of communication is characteristic of B2B markets (EIU, 2007; Gilliland, Johnston, 1997).

The authors of the paper have identified the key motivators for participating in conferences. These themes are official motives related to professional goals, gaining knowledge, establishing new professional relations, etc. An overview of the results of other conferences shows that these motivations apply to those participants too (Anahita, Badaruddin, Ekiz, 2011; Jung, Tanford, 2017; Oppermann, 1995).

Interesting research results were obtained after an analysis of the main factors of the conference selection and their level of fulfilment. In the opinion of EIW participants in Kaunas, the most important factors are 'novelty of the host university' and 'information availability of this EIW'. The university is treated as a conference venue as well as an academic entity (academic centre). This may indicate a great involvement of the participants in the preparation, as well as creating a conference product (consisting of the many other services provided for the participant).

Any business meeting becomes a joint experience of the participants and the organisers and in this context a conference is an attractive product of the contemporary 'experience economy' (Chang, 2018; Stasiak, 2013). A conference meets many different needs therefore it is an example of a modern tourism product (Niemczyk, 2014; Olearnik, 2016). Satisfaction with a service can lead to customer loyalty by repeated purchases (Hallowell, 1996) which, in the context of academic conferences, it is expected that satisfied participants will more likely return in the future.

\section{CONCLUSIONS}

Conferences are complex products on the tourism market. The success of entities involved in their organisation and implementation can be described as the process of identification of their participants and meeting expectations. Conferences includes various forms that can be distinguished according to various criteria (e.g. importance, the scale of internationalisation, impact on the destination, and ways of financing). The authors found that EIW conferences are an interesting contemporary example of a tourist product. The conferences are international, held in many countries, annual (repeated) and financed from EU funds. To identify the success factors of these conferences as tourism products, the authors focused on the opinions of foreign guests participating in the EIW at Kaunas, Lithuania in his research.
The analysis of the distribution of EIW conferences during the year showed that most take place in April and May. Organising such a conference in other months will help the organisers avoid competition and may arouse the interest of the participants.

An important element of conference success is good communication (initiated earlier so that the planners will make decisions in the time provided for in their organisations) and with the use of appropriate forms. Communication is based on direct contact at other events, direct marketing to decision-makers in the institutions from which participants are expected to come.

The content of promotional materials, programs, invitations, should refer to the official motivations related to professional goals, gaining knowledge as well as establishing new professional relations. An important element in the communication will be the presentation of the 'information availability of this EIW' as well as various aspects of the 'novelty of the host university'.

Due to the fact that both superiors and future participants decide, it is necessary to prepare information about the event, the city, the destination very well (in several languages, including transport accessibility, accommodation, general program and detailed events). This may take the form of a website developed for the event, and also a mobile application.

An important factor in the success of a conference is the organisation of a program of accompanying events, in particular sightseeing of the destination and the surrounding area. The participants of international conferences are people from abroad who are very interested in establishing professional contacts and promotion of their own institution, but also exploring the destination and the host country. Therefore, they are seeking and expecting from the organisers that these needs will be met. Participants reach shopping centres by themselves and information about them in promotional materials is not necessary, but such information may make their stay and time spent outside the conference more attractive.

The authors focused on an analysis of selected determinants of the attractiveness of conference meetings. They are aware of the limitations associated with this research and the inference resulting from an analysis of the criteria used and changes in the expectations of participants. The article can provide an example of the methodology of academic research, which in the conditions of economic changes in Europe are an interesting product for business as well as public institutions. Further refinement of success factors, their observation and identification of other conditions for the development of this product, requires research on other types of conference, as well as in other countries.

The success factors of EIW meetings identified in the article can be used by the organisers of academic 
conferences, as well as tourism destination organisations, to develop the attractiveness of their offers and to better organise various services included in such products.

\section{REFERENCES}

Agha, N. (2011). The Economic Impact of Stadiums and Teams. Journal of Sports Economics, 14 (3), 227-252. DOI: https:// doi.org/10.1177/1527002511422939

Ayaz, N., Samata, N. (2017). Integration of congress tourism to the cultural tourism destinations as an economic product. Journal of Tourism and Hospitality Management, 5 (1), 53-61. DOI: https:// doi.org/10.15640/jthm.v5n1a6

Berbeka, J., Borodako, K., Niemczyk, A., Seweryn, R. (2014). Influence of the meetings industry on the economy of Kraków. Cracow: Foundation of the Cracow University of Economics.

Borodako, K., Berbeka, J., Rudnicki, M. (2014). The potential of local KIBS companies as a determinant of tourism development in Krakow. Tourism Economics, 20 (6), 1337-1348. DOI: https:// doi.org/10.5367/te.2013.0351

Borodako, K., Kožić, I. (2016). Cooperation patterns in the tourism business: The case of Poland. Prague Economic Papers, 25 (2), 160-174. DOI: https://doi.org/10.18267/j.pep.552

Breiter, D., Milman, A. (2006). Participants' needs and service priorities in a large convention center: Application of the importance - performance theory. Tourism Management, 27 (6), 1364-1370. DOI: https://doi.org/10.1016/j.tourman.2005.09.008

Chang, S. (2018). Experience economy in the hospitality and tourism context. Tourism Management Perspectives, 27, 83-90. DOI: https://doi.org/10.1016/j.tmp.2018.05.001

Cieślikowski, K., (2014). Rynek turystyki konferencyjnej. Tom I: Podstawy teoretyczne. Funkcjonowanie i rozwój na świecie. Katowice: Wydawncitwo Akademii Wychowania Fizycznego.

Cieślikowski, K. (2015). Business tourism as innovative product for destinations. Innovative (Eco-) Technology, Entrepreneurship and Regional Development, 2, 35-40.

Cieślikowski, K., Brusokas, A. (2017). Determinants of effective management in sport with the use of large sport arenas in selected cities. European Journal of Service Management, 21, 5-10. DOI: https://doi.org/10.18276/ejsm.2017.21-01

Cieślikowski, K., Brusokas, A. (2019). Meetings industry in Kaunas. Report. Katowice: Wydawnictwo Akademii Wychowania Fizycznego.

Crouch, G. I., Ritchie, J.R. (1997). Convention site selection research. Journal of Convention \& Exhibition Management, 1 (1), 49-69. DOI: https://doi.org/10.1300/j143v01n01_05

Crouch, G.I., Louviere, J.J. (2004). The Determinants of convention site selection: A logistic choice model from experimental data. Journal of Travel Research, 43 (2), 118-130. DOI: https://doi. org $/ 10.1177 / 0047287504268233$

Davidson, R., Cope, B. (2003). Business travel: Conferences, incentive travel, exhibitions, corporate hospitality, and corporate travel. New York: Pearson Education, Financial Times.

Dwyer, L., Forsyth, P. (1997). Impacts and benefits of MICE tourism: A framework for analysis. Tourism Economics, 3 (1), 21-38. DOI: https://doi.org/10.1177/135481669700300102

Dwyer, L., Forsyth, P., Spurr, R. (2004). Evaluating tourism's economic effects: New and old approaches. Tourism Management, 25, 307-317.

ECEC (2014). The Erasmus Impact Study. Effects of mobility on the skills and employability of students and the internationalization of higher education institutions. Brussels: The European Commission Educational and Culture.

EIC (2018). Economic significance of meetings to the US economy. New York: Events Industry Council and Oxford Economics.

EIU (2007). Megatrends in B2B marketing. London: The Economist Intelligence Unit.

EMS (2017). Feedback from conference participants. (Report). Dublin: European Meteorological Society.

European Commission (2018). What is Erasmus? Retrieved from: http://ec.europa.eu/programmes/erasmus-plus/about_en (12.08.2019).

Fenich, G.C. (2001). Towards a conceptual framework for assessing community attractiveness of conventions. Journal of Convention and Exhibition Management, 3 (1), 45-64.

Gilliland, D.I., Johnston, W.J. (1997). Toward a model of business-to-business marketing communications effects. Industrial Marketing Management, 26 (1), 15-29. DOI: https://doi.org/10.1016/ s0019-8501(96)00032-6

Gugg, A., Hank-Haase, G. (1995). Die wirtschaftliche Bedeutung des Tagungs- und Kongressreiseverkehrs in Deutschland. Frankfurt: GHH Consult GmbH.

Hallowell, R. (1996). The relationship of customer satisfaction, customer loyalty, and profitability: An empirical study. International Journal of Service Industry Management, 7 (4), 27-42.

ICCA (2007). The international association meetings market 2006: ICCA Statistics Report. Amsterdam: International Congress and Convention Association.

Jung, S., Tanford, S. (2017). What contributes to convention attendee satisfaction and loyalty? A meta-analysis. Journal of Convention \& Event Tourism, 18 (2), 118-134. DOI: https://doi. org/10.1080/15470148.2017.1290565

Lemanowicz, M., Puciata, E. (2010). Czynniki warunkujące sukces produktów turystycznych województwa małopolskiego. Acta Scientiarum Polonorum. Oeconomia, 9 (4), 255-265.

Malaval, P., Bénaroya, C., Digout, J., Szapiro, G. (2013). Business to business marketing from industrial to business marketing: Adaptation from $5^{\text {th }}$ French edition. Bruxelles: De Boeck.

Malekmohammadi, A., Mohamed B., Ekiz, E.H (2011). An analysis of conference attendee motivations: Case of international conference participants in Singapore. Journal of Travel and Tourism Research, 11 (1), 50-64

NBTC (2015). Business meetings in Holland. An analysis of the impact of the industry. Amsterdam: NBTC Holland Marketing.

Niemczyk, A. (2014). Produkty systemowe na rynku turystycznym. Ekonomiczne Problemy Turystyki, 1 (25), 79-99.

Nummela, C. (2017). Delegate Survey 2016 (Rep.). Helsinki: Finland Convention Bureau.

Olearnik, J. (2016). Contemporary marketing in tourist industry. Ekonomiczne Problemy Turystyki, 33, 9-19. DOI: https://doi. org/10.18276/ept.2016.1.33-01

Oppermann, M. (1995). Professional conference attendees' and non-attendees' participation decision factors. The Society of Travel and Tourism Educators, 7 (1), 25-37.

Oppermann, M. (1996). Convention destination images: Analysis of association meeting planners perceptions. Tourism Management, 17 (3), 175-182. DOI: https://doi.org/10.1016/0261-5177(96)00004-0

Pal, D., Joshi, A., Kale, S., Chandel, S. (2015). Likert scale: Explored and explained. British Journal of Applied Science \& Technology, 7 (4), 396-403. DOI: https://doi.org/10.9734/bjast/2015/14975

Rogers, T., Davidson, R. (2016). Marketing destinations and venues for conferences, conventions and business events. Abingdon, Oxon: Routledge.

Sidorkiewicz, M. (2014). Specyfika organizowania konferencji i kongresów naukowych. In: K. Celuch (ed.), Zarzadzanie i organizacja przemystu spotkań w Polsce (pp. 91-103). Warsaw: Szkoła Główna Turystyki i Rekreacji. 
Smith, J. (2018). Who can take part? Retrieved from: http:// ec.europa.eu/programmes/erasmus-plus/about/who-can-take-part_en (17.08.2019).

Staff weeks search (2018). Retrieved from: http://staffmobility.eu/ staff-week-search (10.09.2018).

Stasiak, A. (2013). Tourist product in experience economy. Tourism/Turyzm, 23 (1). DOI: https://doi.org/10.2478/ tour-2013-0003

Swarbrooke, J., Horner, S. (2011). Business travel and tourism. New York: Routledge. DOI: https://doi.org/10.4324/9780080490601

UIA (2018). International meeting statistics for the year 2017. Report. Brussels: Union of International Associations.

UN WTO (2010). The International recommendations for tourism statistics 2008. New York, NY: UN WTO Publishing.

UN WTO (2014) Global Report on the meetings industry. Madrid: World Tourism Organization.
Weber, K., Chon, K. (2009). Convention tourism: International research and industry perspectives. New York: Routledge.

WTTC (2018). Travel \& tourism economic impact 2018 (Report). London: World Travel \& Tourism Council.

Zeithaml, V.A., Parasuraman, A., Berry, L.L. (1990). Delivering quality service: Balancing customer perceptions and expectations. New York: The Free Press.

Zhang, H.Q., Leung, V., Qu, H. (2007). A refined model of factors affecting convention participation decision-making. Tourism Management, 28 (4), 1123-1127. DOI: https://doi.org/10.1016/j. tourman.2006.07.008

Żabiński, L. (2012). Marketing produktów systemowych. Warszawa: Polskie Wydawnictwo Ekonomiczne.

Żemła, M. (2010). Destination brand licensing. In: M. Kozak, J. Gnoth, L. Andreu (eds) Advances in tourism destination marketing: Managing networks (pp. 110-120). London: Routledge.

Article received:

28 August 2019

Accepted:

30 March 2020 